\title{
Who's got the aces up his sleeve? Functional specialization of cities and entrepreneurship
}

\author{
David Audretsch • Oliver Falck • Stephan Heblich
}

Received: 19 May 2008 / Accepted: 22 February 2009 / Published online: 10 December 2009 (C) The Author(s) 2009. This article is published with open access at Springerlink.com

\begin{abstract}
This paper combines the empirical finding of a functional specialization of cities with regional dynamics. We distinguish between cities dominated by headquarters and service firms (urban agglomerations), those with large stand-alone production plants in one sector (industrial agglomerations), and cities with integrated smaller firms (industrial districts). Based on German data, we find differing dynamics across these three city types. Cities that host basic research or integrated incumbents are more conducive to entrepreneurial activity, whereas the opposite is true of industrial agglomerations. Urban agglomerations dominated by headquarters with only administrative functions and the service sector are not very entrepreneur-friendly, either. However, although this type of city provides few externalities for startups in manufacturing, they could very well provide opportunities for service sector startups.
\end{abstract}

JEL Classification $\quad \mathrm{O} 18 \cdot \mathrm{R} 11 \cdot \mathrm{R} 12$

D. Audretsch

Institute of Development Strategies, Indiana University,

1315 East 10th Street, Bloomington, Indiana 47405-1701, USA

e-mail: daudrets@indiana.edu

O. Falck

Ifo Institute for Economic Research and CESifo, Poschingerstr. 5,

81679 Munich, Germany

e-mail: falck@ifo.de

S. Heblich $(\bowtie)$

Max Planck Institute of Economics, Group on Entrepreneurship,

Public Policy and Growth, Kahlaischestr. 10, 07745 Jena, Germany

e-mail: heblich@econ.mpg.de 


\section{Introduction}

Modern agglomeration theories have their roots in Marshall's ideas about external scale economies leading to regional agglomeration. According to Marshall (1920), the costs of transporting goods, people, and ideas are the main reason why firms tend to concentrate in certain regions. Depending on an industry's characteristics, it could be beneficial for it to locate either in proximity to natural resources, suppliers, or customers (Fujita et al. 1999; Krugman 1991) or in proximity to smart people working on similar things in order to benefit from each other's knowledge and insight (Audretsch and Feldman 1996; Griliches 1992; Jaffe et al. 1993; Rosenthal and Strange 2003). Following a formal model by Duranton and Puga (2005), concentrating on either goods production or ideas production results in a functional specialization of cities when firms choose to separate their primary activities, i.e., management and R\&D, from their secondary activities, i.e., actual production. The basic motivation for splitting an organization in this way is to maximize the benefit from regionally bound location factors. An urban environment guarantees diverse knowledge flows, attracts highly skilled people, and provides outsourcing possibilities. By contrast, industrial agglomerations offer a pool of specialized workers, less congestion, and thus better availability of industry parks and proximity to suppliers. Depending on the cost-benefit ratio of an organizational split, however, some firms may very well decide to stay integrated, thereby leading to cities that host both administration and production. In this case, the combination of innovation and production might forge a strong link between theoretical knowledge and practical experience, leading to new ideas that expand the incumbent firm's core business. In time, this process will foster spinoff activity, which, according to Buenstorf and Klepper (2009), is another explanation for regional industry agglomeration.

To analyze the dynamics in these types of regions, we analyze the startup rates in each type. We view startups as a good indicator for regional dynamics because several studies have shown that many radical innovations have their birth in new firms (Audretsch 1995), and that new firms are an important driver of regional employment growth (Fritsch 2008). Furthermore, we know from several studies that entrepreneurship is a regionally bounded phenomenon because entrepreneurs benefit from regionally bounded resources and knowledge flows (Michelacci and Silva 2007; Stuart and Sorenson 2005). Therefore, concentrating on startups as a measure for regional dynamics guarantees that the effect of regional functional specialization on regional dynamics is not influenced by interregional relationships.

Based on a German dataset, our results confirm that there are indeed different dynamics across these three types of cities. Entrepreneurial activity tends to occur most frequently in cities that host either R\&D externalities or integrated incumbents. By contrast, industrial agglomerations of large stand-alone production plants appear to inhibit entrepreneurial activity, indicating that the incumbents are efficient in their knowledge production as they do not generate excessive externalities. This is also true of large metro cities dominated by headquarters with only administrative functions and the service sector. These "service" cities provide few externalities for manufacturing firms; however, they very well could be hotbeds of opportunity for service sector startups. 
The rest of the paper is organized as follows. In Sect. 2, we discuss the characteristics of our three city types and describe their impact on regional dynamics. In Sect. 3 we introduce our empirical method and present the results of same. Section 4 concludes, and offers some suggestions for further research.

\section{Functional urban specialization and dynamics of cities}

\subsection{Functional urban specialization}

A rich body of literature analyzes the location decision of firms (cf. Carlton 1983; Guimarães et al. 2000; Davis and Henderson 2008) and also relates the location decision to the urban transformation process (Henderson 1988). Duranton and Puga (2005) present a formal framework for describing the observable trend that manufacturing firms tend to separate their production from administrative functions and how this trend drives the functional specialization of cities. In their model, firms will choose to split their internal organization as long as the additional costs from coordinating and managing multiple locations do not exceed the benefits from exploiting different regions' locational advantages; otherwise, firms remain integrated. ${ }^{1}$ Firms that choose to split their organization will locate the administration functions in cities that provide better potential for outsourcing certain service functions, such as advertising, accounting, and legal advice, and will locate their production plants in cities where they can outsource production activities.

This functional specialization of cities is one result of the drastic changes that have taken place in the production process over the last few decades. Customers' increasing demand for individualized products requires creativity and quick adjustment to trends in the innovation process, as well as flexibility and smaller batches production-wise. To adapt to these new requirements, large firms implemented two major strategies. First, a steadily increasing number of firms rely on lean production and outsource processes to suppliers instead of producing everything in house (Piore and Sabel 1984; Womack et al. 1990). Second, firms tend to separate administration functions from production (Chandler 1977; Kim 1999; Bade et al. 2003). According to Davis and Henderson (2008), the two strategies are closely interrelated. Service firms are disproportionally concentrated in metro cities and therefore firm headquarters, interested in being able to choose among a large selection of information, advice, and other types of services, are attracted to these cities (Ono 2003). By contrast, manufacturing is more concentrated in medium-size and smaller cities, with headquarters being "not as disproportionally concentrated in large metro areas as is commonly thought" (Davis and Henderson 2008:434).

The empirical finding that headquarters are not actually disproportionally concentrated in metro areas suggests that a considerable number of manufacturing firms choose not to split their organization. Accordingly, there are three possible types of cities, as suggested in the Duranton and Puga (2005) general equilibrium model: urban agglomerations dominated by service firms and headquarters from multi-locational

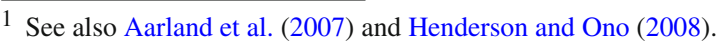


firms; industrial agglomerations dominated by production plants from multi-locational plants in one sector; and cities dominated by integrated firms in one sector. When relaxing Duranton and Puga (2005) assumption of homogeneous firm size, it seems plausible to assume that multi-locational firms are generally large firms while integrated firms are more likely to be small and medium-sized enterprises. These integrated firms are located in smaller cities so that they can take advantage of lower land and labor costs. Over time, these regions will come to resemble the so-called Italian industrial districts (Becattini 1979; Piore and Sabel 1984).

Industrial districts are less studied in the context of urban growth and development as they do not usually give rise to path-breaking innovations and thus do not have much influence on dynamics and growth. Often, they are located in smaller cities that are home to networks of small and medium-sized firms. However, these firms are often highly specialized in one particular phase of production and may have very successfully established themselves in a niche market that large firms cannot satisfy. Indeed, among these firms might well be one or two of the so-called hidden champions, i.e., firms that are leaders in a comparatively small and specialized market (Venohr and Meyer 2007). Although firms in industrial districts are formally independent, they are often interlinked by close relationships, frequently involving family ties, which can result in a sort of district-specific risk management system (Becattini 1990; Amin and Thrift 1992; Callois and Aubert 2007). Markusen (1996, p. 301) characterizes industrial districts as exhibiting "frequent and intensive exchanges of personnel between customers and suppliers and cooperation among competitor firms to share risk, stabilize markets, and share innovation." 2

\subsection{Entrepreneurial activities across cities}

From these very brief descriptions of each city type, it is already clear that their growth enhancing dynamics are based in different sources. As hypothesized by Jacobs (1969), diversified urban agglomerations play a key role in fostering innovation. These places are rich in cultural life and other amenities conducive to a certain lifestyle and worklife balance that attracts highly skilled people (Glaeser et al. 2001; Florida 2002). The concentration of innovative workers along with the presence of business service firms that foster information spillovers create an atmosphere supportive of the early formative and innovative stages of the product lifecycle (Duranton and Puga 2001). However, once the firms "have 'innovated' — settled on a product line or process- they move to ... locales specialized in the activities they will continue to pursue" (Sabel 2002).

According to this line of thought, urban agglomerations are host to firm headquarters and also to basic research laboratories that generate technological breakthroughs and product innovations. As the products of these R\&D departments are likely to spill out into the air, the R\&D departments are instrumental in creating an innovative

\footnotetext{
2 Over time, an industrial district's (ID) ability to adapt to changes in the absence of organizational structures (i.e., to assure a functional division of labor over time) has an impact on whether or not it is entrepreneurial: "A fully developed ID would behave like a collective entrepreneur: It would possess the capacity to redesign process and organization as well as product" (Best 1990:206).
} 
atmosphere marked by externalities in the form of tacit knowledge flows that support the emergence of spinoffs, types of enterprises that are believed to be a driving force of innovation (cf. Audretsch 1995; Klepper 2007). However, if these R\&D laboratories are not integrated with firm headquarters, there will be only very few knowledge externalities available for commercialization by new entrants. ${ }^{3}$ In this case, it is more likely to be the business service sector that provides opportunities for new entrants.

Industrial agglomerations are specialized in production and their organization resembles what Markusen (1996) calls a "hub-and-spoke" structure. In an oligopolistic market, one or a number of large production plants act as the hub. Smaller firms along the supply chain circle the hub like spokes. With regard to small business employment in industrial agglomerations, Markusen (1996, p. 303) remarks that "workers' loyalties are to the core firms first, then to the district and only after that to small firms. If jobs open up in hub firms, workers will often abandon smaller employers to get onto the hub firm's payroll." This leads to an industrial atmosphere characterized by secure employment in large firms that focus on routinized innovation, meaning that R\&D efforts are very tightly focused (Cohen and Klepper 1996; Nelson and Winter 1982). Thus, since innovation activity in this type of city is more likely to be engaged in large firms' specialized research laboratories for their own use, there is very little knowledge spillover, hence few startup opportunities. In this type of city, dynamics result from process innovations that lower large firms' average cost of production.

Finally, in industrial districts, dynamics result from small and medium-sized firms operating in smaller cities where the social and economic spheres are likely to overlap (Bauernschuster et al. 2008). In this environment, friends who work for different firms may swap ideas after work and thus be the conduits for knowledge spilling over from firm to firm (Saxenian 1994). In this way, knowledge becomes a local public good that benefits all firms and individuals connected to the local network (Audretsch and Feldman 1996; Granovetter 1985; Fallick et al. 2006). These intense information flows, along with well-developed social networks, are also likely to increase awareness of entrepreneurial opportunities (Stuart and Sorenson 2005). Because it takes time to become socially embedded, i.e., to set up a dense social network, many entrepreneurs start a business locally where their networks are already well established (cf. Michelacci and Silva 2007; Stam 2007). Generally, this means that they are either life-long residents of the region or have lived there for at least several years (Greene et al. 2008; Keeble and Walker 1994; Saxenian 1999).

The entrepreneurial tendencies of individuals who have previously worked in the region are the particular focus of a detailed spinoff analysis by Klepper and various co-authors. Klepper and Thompson (2007) argue that management decisions to abandon some ideas in favor of pursuing others can lead to sufficient disagreement within the firm such that some employees resign and start a new venture. The authors use the example of several industries to illustrate their theory that disagreement can lead to spinoffs. However, spinning off does not mean that the former employees abandon contact with their former colleagues: to the contrary, they will work to continue these productive social contacts and therefore choose to locate in close proximity to their

\footnotetext{
3 This was the case in financial metropolises such as New York, London, and Frankfurt, and in cities dominated by public administration, e.g., capitals like Washington, DC and Berlin.
} 
former firm (Klepper 2007). This situation leads Buenstorf and Klepper (2009) to the conclusion that spinoff activities are important drivers of industrial agglomeration. In other words, industrial districts' externalities are not in the nature of regional public goods - as might be the case with basic research — but are founded in previous experience and are thus more in the nature of regionally bounded club goods (Bramoullé and Kranton 2007).

In the following empirical section, we test the assumption of differing startup dynamics in manufacturing industries across the three types of cities. We expect positive startup dynamics in cities providing knowledge externalities that can be commercialized by entrepreneurs. These externalities may arise from basic research laboratories in urban agglomerations or from routines in incumbent firms that reveal unexploited niches in industrial districts. By contrast, we expect a negative impact on startup dynamics in industrial agglomerations, where large firms' routinized innovations leave little knowledge to spill out, and in urban agglomerations that are dominated by the service sector and firm headquarters having only administrative functions. This type of city produces no externalities for manufacturing startups; however, such an environment might be very conducive to service sector startups.

\section{Empirics}

\subsection{Exploring functional specialization across cities}

To explore the functional specialization of German cities we focus our analysis on German planning regions. Planning regions consist of several districts and include at least one core city and its surroundings and, therefore, best describe urban regions. Planning regions are defined based on commuter distances and they are thus functional economic units. However, it should be noted in this regard that the cities of Hamburg and Bremen are defined as planning regions even though they are not functional economic units. Therefore, we merge Hamburg with the region Schleswig-Holstein South and Bremen with Bremerhaven and Bremen-Umland. We restrict our analysis to West German planning regions because East Germany has not yet developed a stable industry structure, as compared to West Germany, and thus will not exhibit the same degree of functional specialization as experienced in West Germany (cf. Falck et al. 2008). After this modification, and after excluding Berlin for historical reasons, our final sample consists of 71 West German planning regions.

To distinguish between Duranton and Puga's (2005) three types of functionally specialized cities - cities with only stand-alone headquarters and their business service suppliers (urban agglomerations), cities with only stand-alone production plants in one sector and their intermediate suppliers (industrial agglomerations), and cities with only integrated firms in one sector and their business service and intermediate suppliers (industrial districts)—we calculate regional indicators using employment data from German Social Insurance Statistics (SIS) for 1987-2000.

The Gini index $G_{r}=\sum_{i=1}^{M}\left(s_{r i}-s_{i}\right)^{2}$ of regional industrial concentration in manufacturing. Here, $s_{r i}$ is the employment share of industry $i$ in region $r$ of overall manu- 
facturing employment in region $r$ and $s_{i}$ is the corresponding nation-wide employment share of industry $i$. Looking at the regional employment share of a single industry $i$ relative to its nation-wide employment share, accounts for the possibility that industries vary in their importance across the country as a whole and that some industries are defined more narrowly than others. Consequently, the Gini index is the sum of squared deviations of industry $i$ 's employment share in region $r$ from the nation-wide employment share of industry $i$ where the sum is calculated over all manufacturing industries $M$. The Gini index should be especially pronounced in those city types that are dominated by one industry, namely, cities with only stand-alone production plants in one sector and their intermediate suppliers (industrial agglomeration) or small cities with only integrated firms in one sector and their business service and intermediate suppliers (industrial districts).

The share of a region's employees with a degree in humanities, e.g., business administration, accounting, finance, or law. We expect that these employees are most likely to work in headquarters or in complementary business services. Consequently, the share of employees with a degree in humanities should be especially pronounced in those cities that are home to headquarters, namely, cities with only stand-alone headquarters and their business service suppliers (urban agglomerations) and cities with only integrated firms in one sector and their business service and intermediate suppliers (industrial districts). In addition, we consider the share of employees with a degree in engineering, mathematics, or natural science. We assume that these employees are most likely to be involved in R\&D. The share of employees with a degree in engineering, mathematics, or natural science should be especially pronounced in diverse cities that are home to stand-alone headquarters that also include R\&D laboratories (urban agglomerations).

The Herfindahl index $H_{r}=\sum_{j} z_{j}^{2}$ of regional firm size distribution. The Herfindahl index is calculated over the $j$ firms in manufacturing in region $r$ where $z_{j}$ represents firm $j$ 's regional employment share. It controls for the firm size distribution in a region. We calculate this measure as proposed by Schmalensee (1977). $H_{r}$ takes on a value of 0 for a regional firm structure comprised of a large number of small firms. We assume the Herfindahl index to be small in cities with predominantly integrated firms (industrial districts) as the functional separation of headquarters from production plants (cf. Duranton and Puga 2001) seems especially prominent in large firms (cf. Aarland et al. 2007; Henderson and Ono 2008).

Based on the means of the four indicators over the period 1987 to 2000 we group West German planning regions by means of a hierarchical Ward's linkage cluster analysis (Ward 1963). Figure 1 is the dendrogram for the cluster analysis. We plot only those branches above a dissimilarity threshold of 0.2 , thereby identifying four different branches of planning regions, which are represented by the branch's center ("prototype") planning region. Table 1 shows the branches' means of the four indicators included in the cluster analysis.

The first branch in Fig. 1 (G1) is represented by the planning region of Black Forest-Baar-Heuberg (76). This planning region is characterized by small but highly innovative firms that belong to the metal processing industrial district south of Stuttgart 


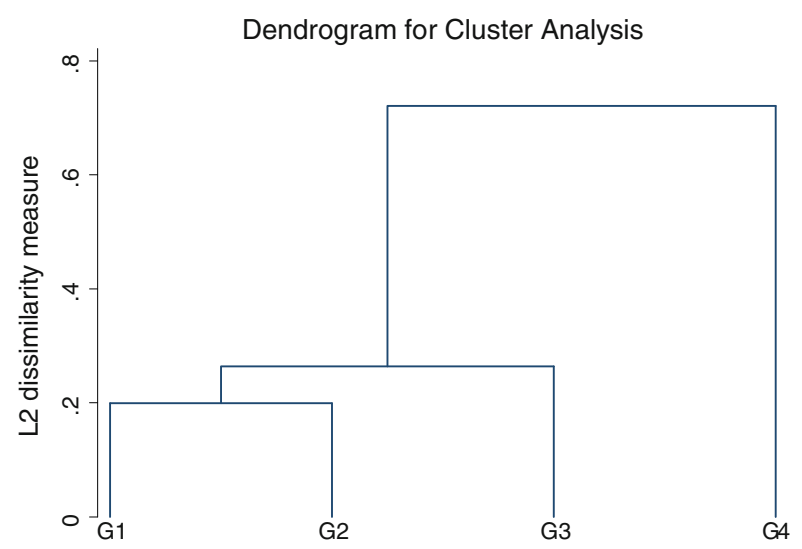

Fig. 1 Dendrogram for hierarchical cluster analysis

Table 1 Means over branches

\begin{tabular}{lllll}
\hline Branch & G1 & G2 & G3 & G4 \\
\hline Prototype & $\begin{array}{l}\text { Black } \\
\text { Forest-Baar-Heuberg } \\
(76)\end{array}$ & $\begin{array}{l}\text { Hamburg } \\
(6)\end{array}$ & $\begin{array}{l}\text { Munich } \\
\text { (93) }\end{array}$ & $\begin{array}{l}\text { Landshut } \\
(92)\end{array}$ \\
\hline $\begin{array}{l}\text { Gini index } \\
\begin{array}{l}\text { Share of employees with a degree } \\
\text { in humanities }\end{array}\end{array}$ & 0.024 & 0.047 & 0.020 & 0.104 \\
$\begin{array}{l}\text { Share of employees with a degree } \\
\text { in engineering, mathematics, or } \\
\text { natural science }\end{array}$ & $1.7 \%$ & $3.2 \%$ & $4.9 \%$ & $2.4 \%$ \\
\begin{tabular}{l} 
Herfindahl index \\
\hline
\end{tabular} & 0.011 & $1.9 \%$ & $3.4 \%$ & $2.3 \%$ \\
\hline
\end{tabular}

that is often mentioned in the literature (cf. Piore and Sabel 1984; Cooke 1996; Porter 1990). The small Herfindahl index confirms the small firm industry structure. Assuming that smaller firms are less likely to separate the firm's headquarters from the production plant, this branch best describes cities with predominantly integrated firms (industrial districts).

The second branch (G2) is represented by the planning region of Hamburg (6). This planning region is home to large publishing houses, design agencies, and also contains Germany's biggest harbor with its extensive service infrastructure. The only considerable industry concentration is the Airbus production plant at the city limits, but this does not, however, interfere with the region's image of being a diverse urban agglomeration as indicated by a relatively small Gini index. A pronounced share of employees with a degree in humanities further underlines the seeming dominance of either headquarters or business services in this region. This structure best describes cities with only stand-alone headquarters of functionally split large firms and business service suppliers (urban agglomeration). 
The third branch shown in Fig. 1 (G3) is characterized by a high share of employees with a degree in engineering, mathematics, or natural science. In these urban agglomerations, headquarters seem to be combined with the firm's research labs. The prototype region of this branch is the planning region of Munich (93). This planning region is characterized by the presence of administrative facilities and connected R\&D laboratories of "global" players. Global players located in Munich include Siemens and BMW. BMW's plant history is a good illustration of Duranton and Puga (2005) concept of functional specialization. Production was historically located in Munich, and still exists there, but the plant's overall share of production has been steadily decreasing while the production plants in Dingolfing, Regensburg, and Landshut have been growing. However, BMW's administration and a large R\&D center are still located in Munich and, recently, the site has been complemented by BMW Welt, a large new building that includes an automobile delivery facility, a museum, and other forms of entertainment.

The fourth branch (G4) is represented by the planning region of Landshut (92). This planning region is dominated by BMW's production plants (Dingolfing and Landshut) and connected suppliers, which is reflected by 46 percent of the employees being employed in the manufacturing sector. A high Gini index combined with a high Herfindahl index confirms the existence of one large firm in a dominant industry. This structure best describes cities with only stand-alone production plants of split-function large firms in one sector and their intermediate suppliers (industrial agglomerations).

\subsection{Entrepreneurship and functional urban specialization}

In a second step, we look at the importance of entrepreneurship across West German planning regions, thereby considering that functional specialization leads to differing levels of startup activity. Entrepreneurship in manufacturing is proxied by the number of startups in manufacturing. Therefore, we are interested in estimating the following equation:

$$
\text { Startups }_{r t}=f\left(\text { Gini }_{r t}, \text { EmpHum }_{r t}, \text { EmpIngnat }_{r t}, \text { Herf }_{r t}, X_{r t}\right),
$$

where Startups is the number of startups in manufacturing in planning region $r$ at time $t$. Gini is the Gini index of planning region $r$ at time $t$ and should capture the impact of industrial agglomeration on startups. EmpHum is the share of planning region $r$ 's employees who have a degree in humanities and should capture the effect of the presence of headquarters on startups. EmpIngnat is the share of employees with a degree in engineering, mathematics, or natural science and should capture the effect of the presence of R\&D on startups. Her $f$ is the planning region $r$ 's Herfindahl index and captures the effect of the firm size distribution on startups. $X$ is a set of control variables and includes a set of year dummies to control time effects, i.e., business cycles; the number of employees (log) in the respective planning region to control for the size of the planning region; and the share of employees in manufacturing in the planning region to control for the planning region's industry structure. 
The number of startups is also derived from the SIS. The information collected can be transformed into an establishment file that provides longitudinal information about the establishments and their employees (cf. Brixy and Fritsch 2004). As each establishment with at least one employee subject to social security has a permanent code number, startups can be identified, that is, the appearance of a new code number can be interpreted as a startup. The unit of measurement is the establishment, not the firm. The empirical data thus derived include two categories of entities: firm headquarters and subsidiaries. As several studies have shown that entrepreneurial startups tend to be small, we exclude new establishments with more than 20 employees in the first year of their existence. As a result, a considerable number of new establishment codes in the data that might be related to the functional reorganization of an existing firm (cf. Duranton and Puga 2001) or to the establishment of a larger branch plant are not counted as entrepreneurial startups.

In addressing the question of whether establishment data are appropriate for analyzing regional startup activity, Grotz et al. (2002) compare the spatial distribution of startups derived from the same establishment file we use with the spatial distribution of startups at the firm level, derived from the German startup panel by the Center for European Economic Research. They show that the spatial structure of startup activity across German planning regions is very similar in both datasets, even though, due to differences in the objectives of the two datasets, startup activity differs in level. This pattern also holds over time. The time-invariant differences in levels should cancel out in our fixed effects regressions as the fixed effects should capture all time-invariant regional effects. Therefore, neither dataset seems to have a particular advantage.

As the number of startups is a count variable, estimating Eq. (1) by means of a classical linear regression model is inappropriate (Blundell et al. 1995). A simple Poisson model will suffice, resulting in the following estimation equation:

$$
\begin{aligned}
& \text { E } \left.\text { Startups }_{r t} \mid \text { Gini }_{r t}, \text { EmpHum }_{r t}, \text { EmpIngnat }_{r t}, \text { Herf }_{r t}, X_{r t}\right)=\lambda_{r t} \\
& \quad=\exp \left(\alpha_{r}+\beta_{1} \text { Gini }_{r t}+\beta_{2} \text { EmpHum }_{r t}+\beta_{3} \text { EmpIngnat }_{r t}+\beta_{4} \text { Herf }_{r t}, X_{r t}\right),
\end{aligned}
$$

where $\lambda$ is the expected number of startups in planning region $r$ at time $t$. The Poisson model has the advantage of being very robust against misspecifications, even though the data are not Poisson distributed (cf. Winkelmann 2008). However, overdispersion, i.e., unobserved heterogeneity, could be a problem. Unobserved heterogeneity is mainly driven by unobserved regional characteristics. If unobserved regional characteristics are correlated with the right-hand side variables, an omitted variable bias will result. To control for unobserved regional characteristics, we add region fixed effects $\alpha_{r}$ to our model. The region fixed effects should capture most of the time-invariant unobserved regional characteristics. As a robustness check, we will estimate a negative binomial count data model to further account for overdispersion. Table 2 sets out descriptive statistics for all variables included in the regression analysis.

Table 3 shows the results of the fixed effects Poisson model and of the corresponding negative binomial model. The results of the two regressions are very similar (cf. Columns I and III of Table 3). Therefore, we restrict our interpretation of the results 
Table 2 Descriptive statistics: planning regions in the period 1987-2000

\begin{tabular}{|c|c|c|c|c|}
\hline Variable & Mean & SD & Min & $\operatorname{Max}$ \\
\hline Gini index & 0.036 & 0.029 & 0.008 & 0.153 \\
\hline $\begin{array}{l}\text { Share of employees with a degree } \\
\text { in humanities }\end{array}$ & $3.0 \%$ & $1.3 \%$ & $1.2 \%$ & $7.6 \%$ \\
\hline Herfindahl index & 0.016 & 0.151 & 0.002 & 0.088 \\
\hline $\begin{array}{l}\text { Share of employees with a degree } \\
\text { in engineering, mathematics, or } \\
\text { natural science }\end{array}$ & $2.1 \%$ & $0.8 \%$ & $0.8 \%$ & $5.1 \%$ \\
\hline Number of employees $(\log )$ & 12.38 & 0.66 & 11.14 & 13.94 \\
\hline Share of employees in manufacturing & $36.2 \%$ & $0.08 \%$ & $18.4 \%$ & $53.8 \%$ \\
\hline Number of startups in manufacturing & 204.33 & 144.92 & 55 & 760 \\
\hline Number of startups in business services & 321.70 & 359.70 & 39 & 2,833 \\
\hline
\end{tabular}

to the Poisson model. Coefficients of Poisson models can be interpreted as proportional effects. Regional industry concentration has a significantly positive impact on startups in manufacturing. Increasing the Gini index by one standard deviation would increase the number of startups by $4.2 \%$. The share of employees with a degree in humanities has a significantly negative impact on startups in manufacturing; increasing the share of employees with a degree in humanities by $1 \%$ point would decrease the number of startups by $4.3 \%$. By contrast, increasing the share of employees with a degree in engineering, mathematics, or natural science by one percentage point would increase the number of startups in manufacturing by $8.02 \%$. The regional Herfindahl index has a significantly negative impact on startups in manufacturing. Increasing the Herfindahl index by 0.01 points $^{4}$ decreases the number of startups by $1.9 \%$.

In an additional specification, we interact the Gini index with the Herfindahl index, assuming that startups can especially profit from externalities resulting from industry concentration in a business environment that is characterized by small firms. Indeed, we find a highly significant coefficient of the interaction term. Again, we restrict or interpretations to the Poisson model as the results of the Negative Binomial model are very similar (cf. Columns II and IV of Table 3). The magnitude of the interaction term causes the positive effect of industry concentration on startups to disappear in the branch of planning regions represented by Landshut (industrial agglomerations), which is characterized by large firms. By contrast, the effect of industry concentration on startups remains positive in the branch of planning regions represented by Black Forest-Baar-Heuberg (industrial district), which is characterized by small firms.

Finally, we shift our attention from startups in manufacturing to startups in business services. Here, we expect the presence of headquarters to create opportunities for startups in business services. The positive coefficient of the share of employees with a degree in humanities in Column $\mathrm{V}$ of Table 3 proves our expectations to be correct. Obviously, startups in manufacturing and startups in business services bene-

\footnotetext{
4 Increase of the Herfindahl index by 0.01 points in the relevant market, for example, raises antitrust concerns in the case of transactions in concentrated markets under the U.S. Horizontal Merger Guidelines.
} 


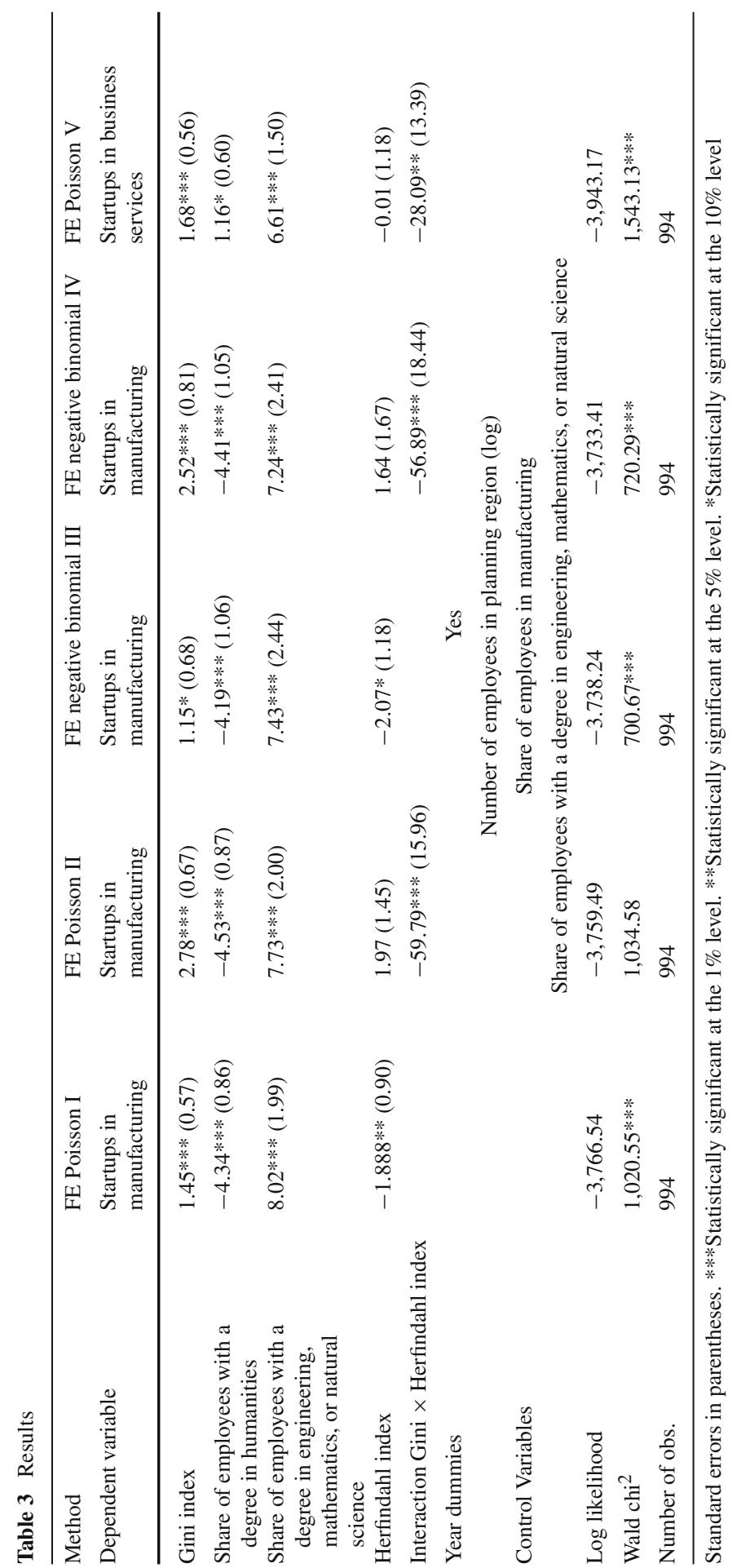


fit from different regional surroundings that are the direct result of functional urban specialization.

Even though we control for time-invariant heterogeneity between planning regions by adding fixed effects and even though we add several time-varying control variables, including a set of year dummies, it is still possible that our results could be influenced by omitted variables. In this regard, the age structure of the regional population could be an omitted variable. Glaeser (2007) attributes a large part of variation in the level of entrepreneurship across US cities to demographic variation. Prospering regions are increasing in population because they attract younger people and offering many entrepreneurial opportunities. By contrast, downsizing regions are experiencing a decreasing and aging population and have very few entrepreneurial opportunities to offer (Boente et al. 2009). Over time, this situation results in an age-specific migration pattern that becomes, in turn, the driving force behind differences in regional age structure within a country (cf. BBR 2006, 12-13; Johansson and Rauhut 2006, 101). However, the number of employees in a planning region that we include as control in our regressions should capture a large fraction of this regional variation. Nevertheless, we are cautious about interpreting our findings as causal effects.

Furthermore, reverse causality could be a concern, i.e., startups shaping the functional specialization of cities. However, this is not too-serious of a concern because functional specialization is to a large extent driven by large firms that have the option of separating their headquarters from their production plants (cf. Duranton and Puga 2001). By contrast, we are explicitly looking at entrepreneurial (small) startups that need time to develop and grow. Indeed, functional specialization of cities is a longterm phenomenon, making us confident that, from an evolutionary perspective, during our relatively short time span from 1987 to 2000 the shape of cities can be regarded as given and as having an impact on startups, not vice versa.

\section{Conclusions}

This paper's goal was to combine the empirical finding of a functional specialization of cities with entrepreneurship. The paper makes two contributions to the existing literature. First, it focuses on industrial districts as less prevalent but nevertheless dynamic regions. Existing literature in the field of urban economics mostly focuses on the functional specialization of cities with urban agglomerations, showing them to be vivid and dynamic centers of growth. However, at a smaller scale, industrial districts and their integrated small and medium-sized firms may well be just as highly innovative. In fact, these regions are often home to so-called hidden champions, which are most likely to be family owned and located in small towns but yet may hold as much as $90 \%$ of the market share in a niche market. The paper characterizes this third category of Duranton and Puga (2005) city types in more detail, by drawing on the extensive but, at least in urban economics, less integrated literature on (Italian) industrial districts.

Second, the paper connects the observable transformation processes in different types of cities to dynamics induced by entrepreneurship by drawing on the extensive literature on agglomeration and functional specialization to develop specific indicators for all types of cities and test their respective impact on startup dynamics. This 
process confirmed our expectations that externalities from basic research laboratories in urban agglomerations and knowledge externalities in combination with experience in industrial districts support entrepreneurship. By contrast, pure production locations and cities dominated by headquarters with only administrative functions leave very few knowledge externalities that can be commercialized by new entrants in the manufacturing sector. However, service providers might very well find good opportunities in these headquarter dominated cities.

To overcome remaining concerns in identifying causal effects of functional specialization of cities on entrepreneurship, it could be worthwhile to analyze shocks that not only change the functional character of a city gradually but also those that do so discontinuously. If there is a causal effect of functional specialization on entrepreneurship, this latter type of shock should lead to a discontinuity in entrepreneurship as well. Such shocks could be the relocation or closure of large headquarters or large production plants in a city. ${ }^{5}$ Depending on the type of existing functional specialization, these events should lead to different impacts on entrepreneurship.

Acknowledgments We are indebted to the editor of the special issue, Andreas Stephan, two anonymous referees, and the participants of the summer meeting 2007 of the German speaking section of the Regional Science Association (GfR) for helpful comments on earlier versions of this paper.

Open Access This article is distributed under the terms of the Creative Commons Attribution Noncommercial License which permits any noncommercial use, distribution, and reproduction in any medium, provided the original author(s) and source are credited.

\section{References}

Aarland K, Davis J, Henderson JV, Ono Y (2007) Spatial organization of firms: the decision to split production and administration. RAND J Econ 38(2):480-494

Amin A, Thrift N (1992) Neo-Marshallian nodes in global networks. Int J Urban Reg Res 16:571-587

Audretsch D (1995) Innovation and industry evolution. MIT Press, Cambridge

Audretsch DB, Feldman MP (1996) Innovative clusters and the industry life-cycle. Rev Ind Organ 11: 253-273

Bade F-J, Laaser C-F, Soltwedel R (2003) Urban specialization in the internet age-empirical findings for Germany. Working Paper 1215, Kiel Institute of World Economics

Bauernschuster S, Falck O, Heblich S (2008) Occupational choice and social contacts across regions. Jena Economic Research Papers 2008-079

BBR (2006) ESPON ATLAS. Mapping the structure of the European territory. Bundesamt für Bauwesen und Raumordnung, Bonn

Becattini G (1979) Dal Settore Industriale al Distreto Industriale. Alcune consideración sull'unitá di indagine dell economía industriale. Revista di Economia e Politica Industriale 1:1-8

Becattini G (1990) The Marshallian industrial district as a socio-economic notion. In: Pyke F, Becattini G, Sengenberger W (eds) Industrial districts and inter-firm cooperation in Italy. International Institute for Labour Studies, Geneva, pp 37-51

Best M (1990) The new competition: institutions of industrial restructuring. Harvard University Press, Cambridge

Blundell R, Griffith R, Van Reenen J (1995) Dynamic count data models of technological innovation. Econ J 105:333-344

\footnotetext{
5 Hamermesh and Pfann (2003) show, using the example of the Dutch aircraft producer Fokker, which went bankrupt in 1996, the value of such econometric case studies.
} 
Boente W, Heblich S, Falck O (2009) The impact of regional age structure on entrepreneurship. Econ Geogr 85:269-287

Bramoullé Y, Kranton R (2007) Public goods in networks. J Econ Theory 135:478-494

Brixy U, Fritsch M (2004) The establishment file of the German social insurance statistics. J Appl Social Sci Stud 124:183-190

Buenstorf G, Klepper S (2009) Heritage and agglomeration: the akron tire cluster revisited. Econ J 119:705733

Callois J-M, Aubert F (2007) Towards indicators of social capital for regional development issues: the case of french rural areas. Reg Stud 41(6):809-821

Carlton DW (1983) The location and employment choices of new firms: an econometric model with discrete and continuous endogenous variables. Rev Econ Stat 65(3):440-449

Chandler AD (1977) The visible hand: the managerial revolution in American business. Belknap, Cambridge

Cohen W, Klepper S (1996) Firm size and the nature of innovation within industries: the case of process and product R\&D. Rev Econ Stat 78:232-243

Cooke P (1996) The new wave of regional innovation networks: analysis, characteristics and strategy. Small Bus Econ 8:159-171

Davis JC, Henderson JV (2008) The agglomeration of headquarters. Reg Sci Urban Econ 38:445-460

Duranton G, Puga D (2001) Nursery cities: urban diversity, process innovation, and the life cycle of products. Am Econ Rev 91:1454-1477

Duranton G, Puga D (2005) From sectoral to functional urban specialization. J Urban Econ 57:343-370

Falck O, Fritsch M, Heblich S (2008) The apple doesn't fall far from the tree: location of start-ups relative to incumbents. CESifo Working Paper 2486

Fallick B, Fleischman CA, Rebitzer JB (2006) Job-hopping in Silicon valley: some evidence concerning the microfoundations of a high-technology cluster. Rev Econ Stat 88:472-481

Florida R (2002) Bohemia and Economic Geography. J Econ Geogr 2:55-71

Fritsch M (2008) How does new business formation affect regional development? Introduction to the special issue. Small Bus Econ 30(1):1-14

Fujita M, Krugman PR, Venables AJ (1999) The spatial economy-cities, regions, and international trade. MIT Press, Cambridge, http://mitpress.mit.edu/catalog/item/default.asp?ttype=2\&tid=8555

Glaeser E (2007) Entrepreneurship and the City, NBER Working Paper 13551

Glaeser E, Kolko J, Saiz A (2001) Consumer city. J Econ Geogr 1:27-50

Granovetter M (1985) Economic action and social structures: the problem of embeddedness. Am J Sociol 91:481-510

Greene F, Mole K, Storey DJ (2008) Three decades of enterprise culture. Palgrave, London

Griliches Z (1992) Patent statistics as economic indicator: a survey. J Econ Lit 28:1661-1707

Grotz R, Brixy U, Otto A (2002) Räumlicher Vergleich der Datengrundlagen zum Gründungs- und Stilllegungsgeschehen in Deutschland. In: Fritsch M, Grotz R (eds) Das Gründungsgeschehen in Deutschland. Physica, Heidelberg, pp 165-198

Guimarães P, Figueiredo O, Woodward D (2000) A tractable approach to the firm location decision problem. Rev Econ Stat 85(1):201-204

Hamermesh DS, Pfann GA (2003) Plant closings, learning and worker displacement. The Death of Fokker Aircraft, Mimeo

Henderson JV (1988) Urban development: theory, fact, and illusion. Oxford University Press, New York

Henderson JV, Ono Y (2008) Where do manufacturing firms locate their headquarters? J Urban Econ 63:431-450

Jacobs J (1969) The economy of cities. Random House, New York

Jaffe A, Trajtenberg M, Henderson R (1993) Geographic localization of knowledge spillovers as evidenced by patent citations. Q J Econ 63:577-598

Johansson M, Rauhut D (2006) ESPON Project 1.1.4. The spatial effects of demographic trends and migration. Swedish Institute for Growth Policy Studies (ITPS), Stockholm

Keeble D, Walker S (1994) New firms, small firms and dead firms: spatial patterns and determinants in the United Kingdom. Reg Stud 28:411-427

Kim S (1999) The rise of multiunit firms in US manufacturing. Explorations Econ Hist 36(4):360-386

Klepper S (2007) Disagreements, spinoffs, and the evolution of detroit as the capital of the U.S. automobile industry. Manage Sci 53:616-631 
Klepper S, Thompson P (2007) Spinoff entry in high-tech industries: motives and consequences. In: Malerba F, Brussoni S (eds) Economic perspectives on innovation. Cambridge University Press, Cambridge, pp 187-218

Krugman P (1991) Geography and trade. MIT Press, Cambridge

Markusen A (1996) Sticky places in slippery space: a typology of industrial districts. Econ Geogr 72: 293-313

Marshall A (1920) Principles of economics, 8th edn. MacMillan, London

Michelacci C, Silva O (2007) Why so many local entrepreneurs? Rev Econ Stat 89:615-633

Nelson R, Winter S (1982) An evolutionary theory of economic change. Harvard University Press, Cambridge

Ono Y (2003) Outsourcing business services and the role of central administrative offices. J Urban Econ 53:377-395

Piore M, Sabel C (1984) The second industrial divide. Possibilities for prosperity. Basic Books Inc, New York

Porter M (1990) The competitive advantage of nations. McMillan, London

Rosenthal SS, Strange WC (2003) Geography, industrial organization, and agglomeration. Rev Econ Stat 85(2):377-393

Sabel C (2002) Diversity, not specialization: the ties that bind the (new) industrial district. In: Curzio A, Fortis M (eds) Complexity and industrial clusters: dynamics and models in theory and practice. Physica, New York, pp 107-122

Saxenian A (1994) Regional advantage: culture and competition in silicon valley and Rte, vol 128. Harvard University Press, Cambridge

Saxenian A (1999) Silicon valley's new immigrant entrepreneurs. Public Policy Institute of California, San Francisco

Schmalensee R (1977) Using the H-index of concentration with published data. Rev Econ Stat 59:186-193

Stam E (2007) Why butterflies don't leave. Locational behavior of entrepreneurial firms. Econ Geogr 83: 27-50

Stuart TE, Sorenson O (2005) Social networks and entrepreneurship. In: Alvarez S, Agarwal R, Sorenson $\mathrm{O}$ (eds) The handbook of entrepreneurship: disciplinary perspectives. Springer, Berlin, pp 211-228

Venohr B, Meyer KE (2007) The German miracle keeps running: how Germany's hidden champions stay ahead in the global economy. Working Paper 30, FHW Berlin

Ward JH (1963) Hierarchical grouping to optimize an objective function. J Am Stat Assoc 58:236-244

Winkelmann R (2008) Econometric analysis of count data. Springer, Berlin

Womack J, Jones D, Roos D (1990) The machine that changed the world: the story of lean production. Rawson and Associates, New York 